\title{
Federalism in Pakistan during Musharraf Regime
}

\author{
Ghulam Ali \\ Lecturer Government Degree College Chowk Azam (Layyah) \\ M Phil Scholar, Department of Political Science, \\ The Islamia University of Bahawalpur \\ Prof. Dr. Razia Musarrat (Corresponding author) \\ Chairperson, Department of Political Science, \\ The Islamia University of Bahawalpur \\ Email: drrazia_mussarat@yahoo.com \\ Muhammad Salman Azhar \\ Department of Management Sciences \\ The Islamia University of Bahawalpur
}

Received:July 07, 2012 Accepted:September 25, 2012 DOI:10.5296/jpag.v2i3.3209

\begin{abstract}
After eleven years of democratic rule Pakistan once again went under military regime when Pervaiz Musharraf imposed emergency in the state by ousting the then elected Prime Minister Mian Nawaz Sharif from his office and started ruling the country with the help of Military junta. This time military stepped in as an institution due to the wrong deeds of politicians. Pervaiz Musharraf declared himself Chief Executive of the state and tried to fulfill his own agenda. He amended the anti terrorism act to punish Nawaz Sharif. Basic pillar of federalism the judiciary remained under fire throughout his regime and Chief Justice of Pakistan was deposed from the office. Political activities and parties were banned. Powers were centralized in the name of devolution of powers. Constitution was abandoned and LFO was introduced to provide victory to the King's party in an engineered elections. Musharraf jumped into war against terrorism and the whole country was facing bomb blasts and attacks of militants on official institutions of the state.
\end{abstract}

Keywords: Federalism, constitution, election, terrorism, military 


\section{Attack on the Federalism}

Muntazara Nazir while discussing problems of federalism in Pakistan writes "Federalism requires a democratic form of government. Dictatorial and authoritarian systems negate the spirit of federalism, accentuate distrust and mutual fear" "Federalism needs democracy for the accommodation of peoples desires and it is also necessary to accommodate diversity in the state. Unfortunately in its 64 years of life Pakistan has to face dictatorship for four times and it derailed the state from the path of solidarity and trust. On 12 October 1999, military broken the 11 years record of its non intervention in politics directly, by ousting Nawaz Sharif from his office. ${ }^{2}$ General Pervaiz Musharraf came into power when he was on tour of Sri Lanka and in his absence Nawaz Sharif appointed General Ziaudin as chief of army staff and dismissed Pervaiz Musharraf from the office of army chief. But army reacted strongly and Sharif brothers along with newly appointed COAS were taken into protective custody. General Pervaiz Musharraf in his televised address stated that army has intervened in politics as a last resort to save the country from destabilization but did not make any gesture that what sort of political system he is going to implement in the country. He declared himself as chief executive of paksitan. ${ }^{3}$

This coup of Pervaiz Musharraf marked as new era in the history of federalism in Pakistan but this all was happened due to Nawaz Sharif autocratic behavior in the country and his some heinous acts against federalism in Pakistan. Free judiciary is a necessary condition for federalism but he managed to resign an interfering chief justice with the help of his colleagues. He forced the head of the state the president to leave the office with the help of army chief and appointed his family lawyer as new president. Democracy and federalism are declared twin matrices and in democracy opposition can play effective role to run the system smoothly. Nawaz Sharif stricken the opposition leader Benazir Bhutto with the charges of corruption and forced her to exile. At the last, he turned towards General Jahangir Kramat and left no option to him except resigning from the charge. and then appointed General Pervaiz Musharraf COAS by super ceding two senior officers of army. Civil institutions which are very necessary for the administration of country were damaged by Nawaz Sharif. Press remained under the fire during his regime and he enacted religious laws in the country, worked in style of Bhutto thinking him unchallengeable. In trying to dismiss his own appointed army chief in his absence from the country, he himself lost his prestigious office of prime minister and was locked up in jail and later exile to Saudi Arabia by making an agreement with army Former law minister of Benazir Bhutto's last cabinet commented on Nawaz Sharif, the intervention in military affairs and stated that "Sharif had the habit of soothing himself in foot. This time he shot himself in the mouth". 4

In his very first address to the nation on October 13, 1999 Pervaiz Musharraf made his resolution to strengthen federalism. He said my singular vision is concern with the well being of the country and of self sustaining policies. The singular concern of my cabinet will be to strengthen the role of federal government and to avoid destabilization of institutions in the state. ${ }^{5}$ The difference of Pervaiz Musharraf's military coup with past three military invention, was that he did not promulgated martial law in the country on contrary he imposed emergency on October 14, 1999 and adopted the title of chief executive.6 Provisions for 
emergency are there in the constitution of 1973 and these provisions declares that president can impose emergency in the federation as a whole or in any part but in critical situations. Musharraf used term emergency only alternative to the martial law to make it acceptable for the nation. He suspended the constitution along with National Assembly, Senate and all provincial assemblies sparing head of the state.6 Unlike general Zia he did not make any promise to the nation of holding fresh elections within 90 days. On October 17, 1999 he addressed the nation on television and presented his seven points agenda which he wanted to achieve. He described these points as (1) reshape the nation's confidence and uplift of the moral of people (2) removing the disparity between the provinces to achieve the purpose of integration among the nation for strengthening the federation (3) rebuilding of investor's confidence to boast the economic condition of the country. (4) Maintain law and order in the state and provision of justice (5) removal of politics from state's main institutions (6) decentralization of powers to the masses and (7) speedy process of accountability to produce a corruption free society in the state. It is very obvious from his agenda that strengthening the federation and decentralization of powers was the main targets of Musharraf regime that are the necessary conditions for federalism. ${ }^{7}$

\section{Amendment of Anti Terrorist Act and Exile of Nawaz Sharif}

After removal from the office Nawaz Sharif and his close companions were taken into protective custody and charged with criminal acts of hijacking and making conspiracy against the federation of Pakistan. But the accusations labeled against the prime minister and others still were beyond the anti terrorist act. To expand its preview the military government amended anti terrorist act given by Nawaz Sharif government to make it trail able for Nawaz Sharif. Senior leaders of PML-N condemned the amendments and accused Pervaiz Musharraf that he wanted to hang the Nawaz Sharif. When this anti terrorist act was imposed in the country it was challenged in the supreme court, thinking it as against the political rights and liberties of the people. ${ }^{8}$ Nawaz Sharif and his party men sated that he has the authority to remove the army chief as being the head of the executive and their case was not subject to deal in anti terrorist court but the stance of military regime was that during Nawaz Sharif regime the representatives of federation on behalf of prime minister has defended the Act in the court. Now they should face the court to defend him. Judge of special court Rehmat Hussain Jafri tried Nawaz and Shahbaz Sharif on April 6, 2000 and awarded life imprisonment to former prime minister and both Sharif brothers were sent to Attock military jail, where they were trailed under national accountability ordinance 1999 on accusation of corruption and wrong deads. ${ }^{9}$ Nawaz Sharif field an appeal in Sindh High Court against his imprisonment.

On December 10, 2000 Nawaz Sharif and his 18 family members were exiled to Saudi Arabia due to a secret deal between Nawaz Sharif and military on behalf of Saudi government.10 The exile was declared in the best interest of the country by the military government, raised serious questions about the validity of national accountability act 1999 and the hegemony of the Punjab. Zulfiqar Khalid writes "the province of Sindh in general and the PPPs leader in particular criticized the exile issue on the touch stone of "double standards" that is convicted Punjabi prime minister Mian Muhammad Nawaz Sharif was pardoned and sent into exile 
while Sindhi prime minister Zulfiqar Ali Bhutto was made to languish in jail and was eventually hanged". ${ }^{11}$

\section{Attack on the Basic Pillar of Federalism, the Judiciary}

In the beginning military government did not exerted much pressure on judiciary and only checked its powers of hearing any appeal against imposition of emergency and issuing any order against the chief executive. Deposed Prime Minister and his party men had filed suits in the Supreme Court on October 12, 1999 under article 184(3) of the constitution for restoration of Nawaz Sharif government and legislative assemblies in the center and provinces. Military government become conscious when these appeals were declared hearable and judiciary fixed January 31, 2000 for hearing. ${ }^{12}$ Earlier in the beginning January 2000 the question of taking of oath came into for front when newly appointed Chief Justice of Peshawar high court Main Ajmal and military government agreed that he would administer oath under the provisions of 1973 constitution. Now situation was changed and to the removal of any possibility by the judiciary of giving judgment against the military takeover in the coming days the military government asked to the judges of Supreme Court and all for High Courts to take fresh oath on January 26, 2000. Before this General Pervaiz Musharraf called the Chief Justice Saeed- uz- Zaman Siddiqui to his office and asked him to discuss the matter of administering new oath under PCO with his colleagues. ${ }^{13}$

On the prescribed day knowing about the intentions of chief justice he was not allowed to go to the supreme court of Pakistan by the security men so that he might not be able to refrain the judges from taking oath . On January 26, 2000 under order No.1 of 2000 as many as 89 judges out of total 103 of the superior judiciary including supreme court, 4 provincial high courts and federal shariat court administrated fresh oath according to the aspirations of the military regime and 16 judges of different categories denied to do so and they were removed from their service. The senior most amongst those who had taken oath was justice Irshad Hasan Khan and he was appointed as the chief justice of Supreme Court of Pakistan. By taking new oath judges pledged that they would perform their duties according to the best of their abilities remaining faithful to emergency imposed on October 12, 1999 and they would act according to the provisions of the provisional constitutional order. In this way judges were bound to provide security and act according to the order of new regime. On May 12, 2000 Supreme Court in the headship of Irshad Hasan Khan made a judgment in response to the petition filed by the deposed government members and showed full commitment to the PCO. In their petition many person prayed to the court to declare martial law ultra constitutional but the court nullified the dismissal of Pervaiz Musharraf by the former prime minister and gave authority to the chief executive to amend the constitutional provisions and awarded him 3 years time to implement his 7 points agenda. These concessions were provided to the regime without its demanding. "The supreme court in its eagerness to validate the military regime, ventured into matters that were not even an issue before the court." ${ }^{\prime 4}$ Till the appointment of Iftikhar Muhammad Chaudhary as Chief Justice of Supreme Court of Pakistan, relations between army and judiciary were going fine but after his appointment situation started changing, when judiciary started hearing those petitions which were filed against legitimacy of military regime and suitability of Pervaiz Musharraf for presidential 
office.

The judicial confrontation with Pervaiz Musharraf started in July 2006 when Supreme Court started the hearing of petitions filed by the Human Rights Commission against the military government. The decision of judiciary proved the real confrontation between the military and the judiciary. This was the first example in the judicial history of Pakistan that the Judiciary realized its authority and it decided to take a stand against the unconstitutional acts of the persisting government and rejected the pressure. The conflict produced an unbridgeable gap between the judiciary and executive. The privatization policy of Musharraf government was also creating tensions between these two organs of the state. Privatization of Pakistan Steel Mill also widened the crises. The Chief Justice Iftikhar Muhammad Chaudhary in response to the news of corruption in the deal took suo moto action against the privatization procedure and indicated irregularities in the process. The judgment came on August 8, 2006. ${ }^{15}$ This issue intensified the relation between the two institutions. This decision further increased the controversy between the two organs which paved the way for forthcoming judicial crises in the country. Now this was the turn of Pervez Musharraf who filed a reference against Chief Justice Iftikhar Muhammad Chaudhary and ousted him from the office on March 9, 2007. He also registered a presidential reference against him. The Chief Justice also decided against his two offices. The crisis continued until the November 2007 when president imposed emergency in the country. The state of emergency put all powers in the hands of president and basic rights and freedoms were suspended. He also suspended the existing chief justice of Pakistan. This act met with a critical and harsh response from the civil society and political parties as well.

According to the President Pervaiz Musharraf: "the suspension was made at the ground of complaints against chief justice for violating the norms of judicial propriety. He was also accused of interfering in the working of the executive branch" ${ }^{\prime 16}$. It was the first time in Pakistan's history that a chief justice was suspended by the head of the state due to his judicial activism. After his suspension a huge mass movement and black coat revolt in favor of judiciary was started in the country. Political parties were also supporting the chief justice and his dismissed colleagues. A constitutional debate also started in the country that whether the president has the authority to suspend the chief justice without the recommendations of supreme judicial Council or not. A constitutional petition was filed in the persisting apex court that established a tribunal to review the case.17 The 13 member bench of Supreme Court of Pakistan in the headship of Justice Khalil-ur-Rehman Ramday reinstated Iftikhar Muhammad Chaudhary as chief justice in a ruling on May 5, 2007. The decision was the result of the conclusion of deliberate hearings of the case. The tribunal unanimously declared presidential action beyond his powers. The bench also pleaded that "Iftikhar Choudhry was to be reinstated and that he shall be deemed to be the office of chief justice and shall always be deemed to have been so long the same. ${ }^{18}$

After his restoration the Chief Justice Iftikhar Muhammad Chaudhary came as the defender of the constitution and judicial activism was further increased. He also made such judgments to restrict the powers of executive. He wanted to create a balance amongst the government institutions. His many decisions on different matters printed deep routed effects on the 
administrative and legislative branches of state. The decisions were not accepted by President Pervez Musharraf and them against his authority. That is why the relations got horrified between the two institutions. In a case of the re-election of Pervez Musharraf as president the Supreme Court gave judgment that president must adopt the legal method. Musharraf thought it against his plan. He immediately reacted and elected himself the president on October 5, 2007 from the existing electoral college. ${ }^{19}$ In another case relating to the eligibility of Pervez Musharraf as presidential candidate the Supreme Court Bench was going to decide whether a government official has the permission to become presidential candidate or not. The decision was likely to come in October-November 2007. The basic objective of the case was to a take a constitutional probe into the matter of holding two offices as Pervez Musharraf had both titles of President and the Chief of Army Staff. The final verdict was expected on November 5, 2007 but Pervez Musharraf imposed emergency in the country using Article 232 of the constitution in the beginning of November, suspended the constitution for the second time in his era and promulgated a Provisional Constitutional Order by replacing the constitution. However he did not dissolved the parliament and provincial cabinets.

In his address to the nation following the emergency President Pervez Musharraf said: "the crisis of extremism and terrorism is rampant in the state. The fanaticism was common in big cities such as Karachi, Sargodha and Rawalpindi. He also propounded that the state was facing a crisis of national integrity" 20 . The Chief Justice reacted sharply to the imposition of emergency. He convened a seven member bench of Supreme Court which issued an interim order against the presidential action. Subsequently the chief justice and several other judges of Supreme Court and provincial courts were removed from their offices. They were all deposed by the presidential order. The new Provisional Constitutional Order (PCO) forced the judiciary to take a fresh oath under the PCO . Fifteen judges of Supreme Court including Chief Justice decoyed to do so. In Addition only a fraction of the judges of supreme and superior judiciary took the new oath. In Punjab 12 out of 31, in Sindh 4 out of 27, in Khyber Pashtunchaw 7 out of 15 and in Baluchistan 5 out of 11 administered their oaths under the PCO. $^{21}$

The crisis gave birth to new issues of judicial review in the state. Protest of lawyers and public once again started in the country and popularity of Musharraf came down to the lowest position, working of administration in the state became a difficult job. The new chief justice Abdul Hameed Dogar that was appointed by Pervaiz Musharraf under Provisional Constitution directed the Chief Election Commissioner and the government to notify Pervez Musharraf as the President of the country for second term by December 1, 2007. The judgment was made by a seven member judicial bench that was appointed by President Musharraf under the provisional constitution. The panel also declared that Pervez Musharraf have to relinquish the office of the Chief of Army Staff before taking the oath as civilian president. The Supreme Court also legitimized the imposition of emergency and the promulgation of the Provisional Constitution Order issued by the Chief of the Army Staff. The larger bench held that President Pervez Musharraf was qualified to contest the presidential election. Furthermore he did not suffer any disqualification under the constitution and the law as well.22 
The black coat revolt once again started in the country. The lawyers from Supreme Court, high courts and the lower courts started a protest against the emergency action imposition of PCO. They were also demanding the restoration of Iftikhar Muhammad Chaudhary and other deposed judges. On October 11, 2007 the lawyers made a call for strike which reacted by the government. However the lawyer's movement continued with great zeal till the restoration of judges in March 2009.

\section{Action against Political Parties and their Reaction}

Anderson says, "Political parties are basic to the functioning of federations. The character of parties and the party system reflects political cleavages within the population and partisan history but it is also significantly shaped by electoral laws and constitutional arrangements. Federation very in having one dominant party, two are more major, or many parties. Normally parties operating at the federal level are linked to those parties which are working within the constituent units" 22 .If it is looked on Pakistan, federal system started in it with one main political party that was Muslim League. During 1947-58 there comes a revolution of political parties on central and provincial level in the federation of Pakistan. These parties raised many issues like the language controversy, regional representation in federal legislature, representational issue of small provinces in civil and military bureaucracy and provincial autonomy within the constitutional sphere. When Ayub Khan imposed martial law, he clamped on political parties and then allows them to work after making changes in the constitution. Attention was not paid to the demand put forward by these gate keepers which resulted in the form of six points of Mujeeb ur Rehman and Agartala conspiracy which after the imposition of martial law by the Yahya Khan led towards dismemberment of federation. In "New Pakistan" when government did not pay any attention towards their demand there started political crises in the shape of Pakistan Democratic Alliance(PDA) and general Zia imposed martial law in the country and he banned political parties with ultra constitutional measures which gave birth to regionalism and issue of Sindh card came in forefront ,PONAM was created national integration was looking at stack but after Zia's death when democracy restored in the country a politics of power sharing started in the country. PPP and PML-N which were working on federal level introduced regional parties like MQM, ANP, parties into mean stream politics at federal level. Although in this era regional parties raised the issue about using river water for agricultural purpose and blamed Punjab for depriving small provinces of their rights but were solved to some extent during Nawaz Sharif era ${ }^{23}$.

After ousting Nawaz Sharif from the office of Prime Minister Pervaiz Musharraf put ban on the political parties and their functioning. Pervaiz Musharraf used Nawaz Sharif originated anti terrorist law to deal with political parties and politicians. Introduction of accountability process in the fashion of Ayub Khan and Zi-ul-Haq against opponents was another check for political parties. Musharraf made two amendment to the anti terrorism ordinance on December 2, 1999. First amendment expanded the jurisdiction of anti terrorist act to those offences and provisions of the criminal code which were not originally came under the preview of the ordinance. These sections were 109, 120, 120B, 121, 121A, 122, 123, 365, 402 and 402b. Among these section 402b which was related to making conspiracy for hijacking, allegedly included for Nawaz Sharif trail. The second amendment to the 
constitution in the act was about setting two new anti terrorist courts in the country, one in Lahore and the other in Karachi. After this Nawaz Sharif was trailed and was sentenced to life imprisonment and after that by making a deal was exiled to Saudi Arabia. It is interesting to note that other main leader of federal level party, which was already in abroad due to policies of Nwaz Shrief, in the beginning welcomed Martial Law but later knowing about the intentions of Pervaiz Mushrraf when he reopened cases against her too, she started opposing martial law regime. ${ }^{24}$

\section{Devolution or "Centralization" of Power Plan}

Introduction of local government system on non party bases and using these local government representatives in their own interests whether in the form of Basic Democracies system of Ayub Khan, Local government scheme of Zia ul Haq or the Devolution of Power Plan of Pervaiz Musharraf remained a favorite method of dictators for centralization of power in Pakistan. Pervaiz Musharraf promised the people for decentralization of powers in his seven point's agenda in complying with his promise and in reply to the immense international pressure for restoration of democracy which has exerted due to his over throwing the democratic regime, he announced that local bodies election would be held this year all over the country. He made this announcement only two days before the schedule visit of Bill Clinton on March 23, 2000. On the occasion of Independence Day he delivered a speech on radio and television in which he announced the features of Devolution of power plan and said that process for local bodies' election would be started on December 2000 and would end on May 2001. In a second phase election would be held for district level in July 2001. According to him by this act of devolution municipal government will renew in the country. In justification to his decision he stated that it would be the beginning of democracy and this process would lead us towards elections for federal and central legislatures respectively. But according to many writers who had written on this subject Musharraf wanted more beyond the devolution of power to the masses. On November 16, 1999 he gave these tasks to highly powerful National Reconstruction Bureau (NRB) to frame a local government plan. The NRB acted upon the advice and prepared a draft for this plan in May 2000. According to this proposal it was a third tier system comprising on union, Tehsils and District councils. It was said that this system would be a change regards to the Basic democracy system and Local bodies system of Ayub Khan and Zia ul Haq. These councils would be provided with enough power and financial resources to meet their needs and reconstruct plans for the development of people at local level. It was explained that the top level representative of the people at district level would be District Nazim and he would be authorized to dismiss or transfer the executive head of the district.

A district government would be comprised on District Nazim as the head of the District government, DCO, the head of civil bureaucracy in the district and would coordinate the district Nazim in administration of his task. All the Nazims of union councils of a district would be the members of district council. Naib Nazim of the district would act as the speaker of the district assembly .12 departments were placed under the district government.

Under the district government would came the Tehsil government Nazim would be its head 
and he would administer his functions with the help of TMO (Tehsil Municipal Officer) Tehsil council would be comprised on all Naib Nazims of union councils coming under the jurisdiction of Tehsil. Tehsil's Naib Nazim would perform as speaker of the Tehsil Council. Under this tier would be the union council and this would be the lowest level. All members of this council would be elected with the Nazim and Naib Nazim of the council directly by the people of the union council. Union government would comprise on Nazim, Naib Nazim and union council which would administor its functions with the help of three secretaries. This council would resolve the problems of people at local level. Metric was fixed educational qualification for all the Nazim and Naib Nazim of district whether at union, Tehsil a District Level. This devolution of power plane changed the whole scenario of administrative authority and bureaucrats for the first time came under the control of elected people in districts of Pakistan. Representation was fixed for women and minorities at all levels and for laborers and farmers at union level. For the implementation of this system departments at district level were restructured. Additional funds were provided to District and Tehsil governments to meet their needs. The election process for this plan was completed in July $2001^{25}$.

\section{Decentralization of Powers and Police Order of 2002}

Devolution of power plan changed the legal structure of police. In August 2002, police Order of 2002 was imposed by the Musharraf, according to which Superintendent of police was renamed as District Police Officer (DPO) which was bound to work in harmony with District Nazim to perform his duties: Other than administration of district police, investigation of criminal cases and police functions relating to prosecution. Nazim was authorized to write ACR of DPO. It was explained in police order to establish checking authorities on police comprising on public representatives and nominated members at district, provincial and national levels. For further control on police an independent prosecution service was maintained. According to the constitution law and order came under preview of the provinces and new police order formulated by federal government created resistance and uneasiness among provinces which aggravated distance between center and provinces which was very harmful for the federal system in Pakistan. The worries of provinces was understandable because central government used police authorities later for getting desired results in local government elections and for gathering support in presidential refrendum.Police was also used for suppressing regional rivals of the regime. ${ }^{26}$ This decentralization of power by Musharraf viewed by many politicians as centralization of authority to consolidate his position and to foster power for himself. A cursory glance over the scheme states that this was implemented to generate a new power hub for military regime. It was the negation of provincial autonomy at the expense of the increase of authority for central government. It was also termed as the distribution of political process. Main political parties of Pakistan showed a strong reaction against the plan and described it as an "old wine in a new bottle" 27 and related this system to Ayub Khan BDs Scheme. They termed it a try to prolong the military rule in the country. Political parties had no role in the whole scheme which was against the set norms of federalism. It is impossible to introduce democracy at local level without the help of political parties ${ }^{28}$. 


\section{Constitution beyond the Constitution (LFO)}

All federation of the world reflects that there is no authority of judiciary to confer generals such powers through which they can change constitution according to their desires. But supreme court of Pakistan done this and this was unmatchable in the history of federalism. Constitution of Pakistan does not allow such powers to judiciary. In Zafar Ail Shah case when judiciary gave its judgment by legalizing the Musharraf regime the apex court authorized him to make constitutional changes "if the constitution fails to provide a resolution for attainment of his declared objectives" 29 . But this authority was curtailed by an explanation that "no amendment shall be made in the salient features of constitution that is independence of judiciary, federalism, parliamentary form of government blended with Islamic provisions" ${ }^{\text {" }}$. These restriction did not meant for a general who had unlimited authority over every institution and every legal document of the state. In the fashion of Zia-ul-Haq he also wanted to protect his un-constitutional measures. But here was a difference Zia legitimized all his commandments and ordinance though passing them in the parliament with negotiations, requests; threats in the form of the $8^{\text {th }}$ amendment but Musharraf had no need to do all this. He had shelter provided by the judiciary to amend the constitution at his own expense. He promulgated Legal Frame Work Order (LFO) and horrified the federal legislature that if it made any effort to repeal any of his amendments in the law of land particularly relating to the National Security Council "They will have to quit or I will quit" ${ }^{31}$ Legal documents prepared for establishment of sustainable democracy revealed to the people step by step. Its first installment made to the public on June 26, 2002 and second Installment on July 15, 2002. The legal structure to enhance "Political stability" and "checks and balances in the power Structure" of the state was based on following characteristics ${ }^{32}$. Age of voters was fixed at 18 years by reducing previous fixation that was 21 years.

1. According to original provision of 1973 constitution joint elections in the country introduced without reserving any seat for minorities.

2. Power of removing of prime minister and his ministers without vanishing the lower house was conferred to the president.

3. Power of appointment of governors in the provinces and nomination of prime minster given to president.

4. Governors were empowered for the nomination of chief ministers in the provinces.

5. National Security Council was formed with president as its chairman.

6. Members of upper house will be elected indirectly by the members of provincial Assemblies.

7. Elections of Senate will be held on party basis and sanction was imposed on independent candidates.

8. Graduation was the pre request for the membership of parliament.

9. Assembly strength was increased 51 members ship national assembly was 
enhanced to 357 contrary to previous 207

10. Seats of senate were increased from 87 to 100 by assigning 22 seats to every province.

11. Increase made in provincial legislature was as, Punjab 240 to 390, sindh 100 to 171 NWFP 80 to 130 and Baluchistan 40 to 67.

12. Number of seats reserved for technocrats, Ulema and women in the central and provincial legislature were increased.

13. Qualification for technocrats was fixed 16 years of education recognized by the higher education commission.

14. On completion of tenure of Assembly a care take government will hold elections in country

15. Ban was put on Banks defaulters for contesting elections.

16. Parties having less than $10 \%$ votes in assemblies for general election will not be given to them reserve seats in Assemblies while less than 5 percent votes make them ineligible for senate seats.

17. Local governments were provided shelter for their working ${ }^{33}$.

Legal Framework Order raised a discussion throughout the federation. Political leaders, legal and constitutional experts and different organizations raised the question about the validity of constitutional package. They all described it for the centralization of powers for the President. Pervaiz Musaraf introduced changes in the constitution and felt no need to legitimize them in the coming parliament. He extended his tenure for five years and declared himself as the president of the country. He gathered powers to dissolve the assemblies by renewing $58(2) \mathrm{b}$ and national Security Council was introduced through new Article 152-A. Through this legal framework order Musharraf got all powers relating to the appointment of army chiefs, and governors and nomination of prime minister making him only a secretary of president. This was against the spirit of parliamentary system. President became the fountain head of all powers and system of government resembled to presidential form of government. The changes in the constitution without consulting the representative of people proved harmful for federation in the coming years ${ }^{34}$. With unlimited powers in his office president adopted several measures against the integration of the federal system including waging a war against terrorism, killing of Akbar Bugti and army action in different parts of the federation without consulting the federating units ${ }^{35}$.

\section{Engineering Elections:}

Decision given in the case of Zafar Ali Shah not only legalized the army coup but also restricted it to hold elections within three years i.e. October 12, 2002. So he announced that election would be held on party basis within the prescribed time and his hand made National Accountability Bureau (NAB) decided to engineer the elections. NAB presented political parties ordinance according to the will of the president that restructured election rules to get 
desired results. It ordered political parties to present their manifesto before election. It promulgated the condition of graduation for the candidates of National and provincial Assemblies in the coming elections. That was only meant to block the way of some known and seasoned politician of political parties, who did not hold the required qualification. The ordinance also restricted those politicians to contest elections who were disqualified on charges of corruption or criminal activities under Article 63 of the constitution of Pakistan from holding any public office. Article 63 of 1973 constitution was also changed through LFO and people who did not pay their utility bill and loans taken from banks also convicted under this article. The qualification to hold public offices order 2002 prevented any politician to hold the office of prime minister for two times. This was clearly against the leaders of two federal based parties PPP and PML-N. Joint electorate were introduced in the country for the first time after post Zia period. For strengthening federalism minorities were brought in national politics by reserving 10 seats for them in National Assembly with indirect and proportional representation. 60 seats were reserved for women to reshape the gender face of politics. These seats were also to be filed indirectly according to the strength of different parties in National Assembly. Ban on political parties was lifted in September. Two main political leaders Benazir Bhutto and Nawaz Sharif were restricted from taking part in elections. Nomination papers of Benazir Bhutto were rejected and she moved to UNO against this act. While Nawaz Sharif who was exiled in Jeddah withdrew his nomination papers in protest against military government by accusing Pervaiz Musharraf for violating basic rights of the people of Pakistan. Now after 1988 field was open for new leadership to become Prime Minister of Pakistan .General reaction of the people in federation was sluggish about these elections. Their opinion was that nothing is going to change in the country. While little much damage was done to federalism by debarring two main leaders of two federal based parties from two influential provinces of Pakistan to take part in politics ${ }^{36}$.

In the Nawaz Sharif era two main alliances emerged is National politics in the name of Motahida Majlis Amal (MMA) and Grand National Alliance) GNA were still in integrated position. MMA mainly comprised on all religious parties of Pakistan and under the leader ship of Shah Ahmad Noorani proved an effective tool for strengthening federalism in Pakistan. But in the election another king's party in the name of PMLQ which was mainly comprised on politicians from PML-N and PPP who were shifted to make a new party only for political gains under government pressure also emerged as a major power ${ }^{37}$.

Besides these all proceedings old rivals PPP and PML $\mathrm{N}$ also joined hands for restoration of democracy under the leadership of Nawabzada Nusraullah Khan but failed to make seat adjustments due to local rifts.

On October 10, 2002,elections were held for 272 general seats of National Assembly and 577 seats of provincial assemblies. 
Table-1

\begin{tabular}{|l|l|l|l|l|l|l|l|l|l|}
\hline & PPP & PMLQ & PMLN & MMA & NA & MQM & ANP & ND & Other \\
\hline Punjab & 34 & 66 & 15 & 9 & 7 & - & - & 15 & - \\
\hline Sindh & 27 & 4 & - & 7 & 5 & 13 & - & 1 & - \\
\hline NWFP & - & 4 & - & 29 & - & - & - & - & - \\
\hline Baluchistan & - & 2 & 1 & 6 & 1 & - & - & 1 & - \\
\hline FATA & - & - & - & 7 & - & - & - & 5 & - \\
\hline Total & 62 & 76 & 16 & 53 & 13 & 13 & - & 22 & 1 \\
\hline
\end{tabular}

Source: $\quad$ Ian Talbot, Pakistan: A Modern History, p. 405

Table-2

Provincial Elections Result 2002 ANP

\begin{tabular}{|l|l|l|l|l|l|l|l|l|}
\hline & PPP & PMLQ & PMLN & MMA & NA & ANP & ND & Other \\
\hline Punjab & 60 & 127 & 37 & 6 & 12 & - & 39 & - \\
\hline Sindh & 50 & 10 & - & 13 & 12 & - & 5 & 1 \\
\hline NWFP & 8 & 8 & 5 & 48 & - & 8 & 12 & 1 \\
\hline Baluchistan & 2 & 8 & - & 14 & 3 & - & 7 & 1 \\
\hline Total & 120 & 153 & 42 & 81 & 27 & 8 & 63 & 3 \\
\hline
\end{tabular}

Source: Ian Talbot, Pakistan: A Modern History.

Results of elections show the following trends.

PML-N lost its majority, MMA emerged out an equal contender at national level, and no party gain any majority in the elections and a hung parliament came out from the elections ${ }^{38}$. MMA's victory at reasonable seats was the most striking feature of these elections. MMA victory was also a healthy sign for federalism in different ways. Firstly under the banner of MMA almost all religious parties of Pakistan representing different sects gathered. In this 
way ethnicity on religious grounds came to an ended during this era. Shia Sunni conflict which inflamed the Pakistan before Musharraf era was resolved to some extent. Secondly MMA largely draw its popularity from Khyber Pakhtun Khwa and Baluchistan and formed its governments there by ousting regional parties from the politics of these two provinces. MMA succeeded due to many reasons. There were many flaws in election process that is why many politician termed coalition of MMA with PMLQ as "Mullah Military Alliance" they took benefit from their concentrated popularity in particular areas. Finally American attack on Afghanistan proved a reason of their popularity. MMA always condemned the American invasion in Afghanistan. Pashtun of NWFP and Baluchistan always supported Afghanistan due to their ties with Pashtun nation of their country. Anti American sentiments help MMA to gathered support in Pashtun areas. "The success of MMA was demonstrated by the fact that the nationalist parties representing pashtun in NWFP were all but wiped out in this election because they did not condemn the invasion of Afghanistan"39.

Stephan Cohen concluded about the MMA success that "the rise of Islamic parties in the NWFP and Baluchistan may be a sign that Islam is now the vehicle of Pashtun nationalism" 40 .

MMA's success provided relief to federalism in Pakistan in another way. Many factions of MMA were not in favoring of "ethnic Nationalism" they won seats in all legislatures of Pakistan. They were in support of a central government and believed in principles of federalism. If their unity prolong in the coming years they could minimize the regional sentiments in KPK and Baluchistan. But on the other end victory of MMA also became a source of threat for federalism in Pakistan. When the regionalist leaders saw support of central government for MMA. They started activities against federal structure of the country. Sardar Akbar Bugti of Baluchistan was one of them who reacted against the centre strongly ${ }^{41}$.

\section{War against Terrorism and its Effects on Federation of Pakistan}

After the terrorists attacks on world trade centre and pentagon in America on September 11, 2001 Pakistan was forced to change its domestic, regional and foreign policy. It was also termed as a U turn in Pakistan's policy and Pakistan became frontline ally against war on terror in the world when president of America threatened Musharraf to become ally or enemy. War on terror was mainly war against Afghanistan and within 10 years Pakistan once again indulged in the war of others ${ }^{42}$. Like the first which was the war of America and Russia in 1979 the new war of America which was so called against terrorism caused serious danger for the federation of Pakistan. 40 thousand of peoples including five thousand army men have lost their lives in this war against terror till February 2012.more than 20 billion US dollars of loss has to bear Pakistan economy ${ }^{43}$. Suicide bombing, attacks on police stations, military cantonments, mosques, shrines and public places in Pakistan and terrorist attack on foreign cricket team like that of Sri Lanka are due to this war against terrorism. This all Pakistan is facing due to wrong policy of a military dictator who occupied the country but surrendered to America. America suspected that the master mind of terrorist attacks on America Osama Bin Laden has taken refuge in Afghanistan and Taliban government is patronizing him. In 1980 this Osama Bin Laden was the most reliable person for America in the war against 
communism. In the words of Veena Kukreja "Osama Bin Ladin, the most wanted man in the world and the perceived symbol of evil, received his first lesson in the art of clandestine operations and subterfuge from the CIA. Bin Laden the legendry US ally of 1980's became dreaded terrorist of the 1990s and the most privileged guest of the Taliban"44. Taliban were nurtured both by America and Pakistan for the strategic objectives. America wanted to control over Iran and the gulf oil by bringing up Taliban but Pakistan's objectives were different. It wanted a friendly neighbor in the form of Afghanistan. It also wanted to use Taliban against India in war like situation but 9/11 attacks turned the whole scenario. After the arracks on the one side were America who was very necessary for Pakistan due to its failing economy, fear of India and for remaining as an important actor in the globalist world. But on the other hand was Taliban who were waging war in the name of Jihad. America can reduce Pakistan to nothing, caused bankruptcy and isolation in the world politics and Taliban had threatened to do Jihad against every state that would help America. In this situation Musharraf was left with no option except to become part of those states that were ready to fight war against terror $^{45}$.

America offered Pakistan lifting of sanctions imposed in 1998 after atomic explosions, writeoff loans, economic help and support on its Kashmir policy. In return Pakistan was agreed to intelligence sharing, logistical support, use of air space and infrastructure ${ }^{46}$. This was very risky decision of Pakistan for its integration to support USA because Pakistan is a federal country splitting on racial ethnical, linguistic and ideological grounds. People of its two provinces Khyber Pakhtun Khwa and Baluchistan has direct ideological linguistic and even blood relations with the people of Afghanistan. More over factions in army and civil society has sympathies with Taliban on ideological grounds. People of federally administered tribal areas were very strict in their ideological relations with Taliban. Musharraf was to face the anger of all these elements and such was happened ${ }^{47}$. When US launched its attack against Taliban many war lords and Jihadis entered into remote areas of southern Waziristan, Swat and other tribal areas. In reaction to Pakistan support to America they started suicide bombing attacks in Pakistan which caused panic in cities of Pakistan and feared the people. They captured tribal areas and posed a serious threat to Pakistan's stability. To counter this situation Musharraf government started an operation in Waziristan for cleaning up these areas from the militants ${ }^{48}$

\section{Conclusion}

History of Pakistan shows whenever there was political destabilization in the country military got an opportunity to rule the country but this rule of military always created problems for the federation of Pakistan. Military regimes introduced changes in the constitution, gate keepers the political parties were not allowed to work and judiciary remained in the line of fire. Moreover centralization of powers produced unrest at provincial level that proved fatal for the federation of Pakistan. 


\section{References}

1. Veena Kukreja, Contemporary Pakistan Political Process Conflicts and Crises, Sage Publications, New Dehli/Thousand Oaks/London.

2. Ian Talbot, Pakistan:A Modern History, Foundation Book New Dehli, Banglore, 2009.

3. Hamid Khan,Consttutionand and Political History of Pakistan, p.267.

4. Charles H. Kennedy, Political Issues in Pakistan: In 2004, in Charles H. Kennedy, Cynthia Botten (eds), Pakistan: In 2005, (New York: Oxford University Press), 2006, pp.3-4.

5. Charles, H. Kennedy and Cynthic Botteron, Pakistan, 2005. p. 257.

6. Craig Baxter, Pakistan on the Brink, Oxford University Press, 2005, p. 145.

7. Ian Talbot, Pakistan A Modern History, New Dehli, Banglore, 2009.

8. Ibid.

9. Tahir Kamran, Democracy and Governance in Pakistan, South Asia Partner Ship-Pakistan, p.176.

10. Craig Baxter, Pakistan on the brink, Oxford University Press, 2005, p. 179.

11. Charles, H. Kennedy and Cynthic Botteron, Pakistan, 2005.

12. Iqbal S. Hussain, Crises, Crises and Crises, Pakistan: A Proud Nation but Failing State Humanity International, 2007, p. 196.

13. The Post, Lahore, July 25, 2006.

14. Dawn, Karachi, August 9, 2006.

15. The News, Lahore, September 15, 2007.

16. The Nation, Lahore, May 6, 2007.

17. Daily Khabrain (Urdu), October 6, 2007.

18. The Nation, November 6, 2007.

19. Ian Talbot, Pakistan A Modern HistoryNew Dehli, Banglore, 2009.

20. The Nawa-e-Waqt, Lahore, December 02, 2007.

21. Kathrine Adney, Palgrave Macmillan, Federalism and Ethnic Conflict Regulation in India and Pakistan, 2007, p. 157.

22. Veena Kukreja, Contemporary Pakistan Political Process Conflicts and Crises, Sage Publications, New Dehli/Thousand Oaks/London.

23. Ian Talbot, op.cit., p. 305. 
24. Tahir Kamran, Democracy and Governance in Pakistan, South Asia Partner Ship-Pakistan, p.176.

25. Ibid.p.197.

26. Ibid.p.197.

27. The Dawn, Internet Addition, 2008

28. The Police Order 2002,updated version, compiled by ops wing NRB August 2007

29. Daily Times August 26,2007

30. Ian Talbot, Pakistan A Modern History, foundation book New Delhi, Bangalore, 2009.

31. Tahir Kamran, Democracy and Governance in Pakistan, South Asia Partner Ship-Pakistan, p.176.

32. Ibid.

33. Ambreen Javed, Concerns of Baluchistan: Effects and Implications for Federation of Pakistan, Journal of Political Studies, Vol.I, Issue 2, 113-115.

34. Charles, H. Kennedy and Cynthic Botteron, Pakistan, 2005.

35. Tahir Kamran, Democracy and Governance in Pakistan, South Asia Partner Ship-Pakistan, p.176.

36. Ian Talbot, Pakistan A Modern History, foundation book New Delhi, Bangalore, 2009.

37. Kathrine Adney, Federalism and Ethnic Conflict Regulation in India and Pakistan. Palgrave Macmillan

38. Ibid.

39. Iqbal S. Hussain, Crises, Crises and Crises, Pakistan: A proced Ntiaon But Failing State Humanity international.

40. The Nawa-e-Waqt, Multan, February 22, 2012.

41. Veena Kukreja, Contemporary Pakistan Political Process Conflicts and Crises, Sage Publications, New Dehli/Thousand Oaks/London.

42. The Hindustan Times, Internet Addition, September 20, 2007.

43. The Dawn, Internet Addition, October 17, 2007.

44. Kathrine Adney, Federalism and Ethnic Conflict Regulation in India and Pakistan, Palgrave Mamillan

45. Ihtisham-ul-Haq, President Warns of Quitting War against Terrorism, Dawn Internet Addition, April 13, 2007.

46. Noor ul Haq Pakistan:Avictim of Terrorism December 29,2008 pp1-2 
47. Charter of Democracy, quoted in Pakistan Times, Islamabad, May 16, 2006.

48. Ibid. 